\title{
IL18 wt Allele
}

National Cancer Institute

\section{Source}

National Cancer Institute. IL18 wt Allele. NCI Thesaurus. Code C50925.

Human IL18 wild-type allele is located within 11q22.2-q22.3 and is approximately $21 \mathrm{~kb}$ in length. This allele, which encodes interleukin-18 protein, is involved in the regulation of both pro-inflammatory cytokine production and biological activity. 